\section{Alternative Ridging Practices for Flue-Cured Tobacco Production in North Carolina}

\author{
Matthew C. Vann,* Loren R. Fisher, \\ Randy Wells, David L. Jordan, and \\ Joshua L. Heitman
}

\begin{abstract}
With increasing farm size and the necessity for timely field preparation, flue-cured tobacco (Nicotiana tabacum L.) producers in North Carolina would benefit from alternatives to current ridging practices. Research was conducted in 2012 and 2013 to evaluate the effects of differing ridging methods on soil physical properties and the growth and development of flue-cured tobacco. In each environment, two alternative ridging methods were compared with the grower standard of spring ridging (SR): fall ridging (FR) and rotary ridging (RR) in the Piedmont, and FR and no ridging (NR) in the Coastal Plain. In the Piedmont, FR reduced leaf yield and value when compared with RR and SR systems. Reduced yield and value were a result of high soil resistance that inhibited plant growth. In the Coastal Plain, treatments imposed did not affect the soil physical properties or tobacco yield and quality. Results indicate that FR and NR systems are acceptable alternative ridging methods for the production of flue-cured tobacco in the sandy Coastal Plain growing region. Alternatively, FR should not be used in the Piedmont growing region due to the fine soil texture that is prone to high resistance.
\end{abstract}

$\mathbf{F}$ lue-cured tobacco is most commonly produced in a conventionally tilled and ridged (bedded) system that includes multiple posttransplanting cultivations. Yield increases have been documented in flue-cured tobacco when ridging is compared with flat cultivation in seasons characterized by high rainfall (Peedin, 1999). Collins and Hawks (2013b) have suggested that a high, wide row ridge promotes water drainage away from sensitive tobacco roots, reduces fertilizer losses, and increases soil temperature-all of which are beneficial to tobacco growth. Ridging is commonly performed 1 to 4 weeks in advance of transplanting, once environmental conditions become favorable, and is often completed with the aid of in-row subsoil tillage. Vepraskas and Miner (1986) reported increased root growth and decreased mechanical impedance when subsoiling takes place prior to transplanting. Subsoiling practices can reduce soil resistance from $>25$ bars to as low as 12 bars, thus allowing for deeper tobacco root penetration below the Ap soil horizon (Vepraskas and Miner, 1986). Due to the correlation of soil resistance and soil bulk density (BD), root growth and biomass accumulation of potted and field-grown tobacco plants are increased when $\mathrm{BD}$ and soil resistance are decreased below 1.66

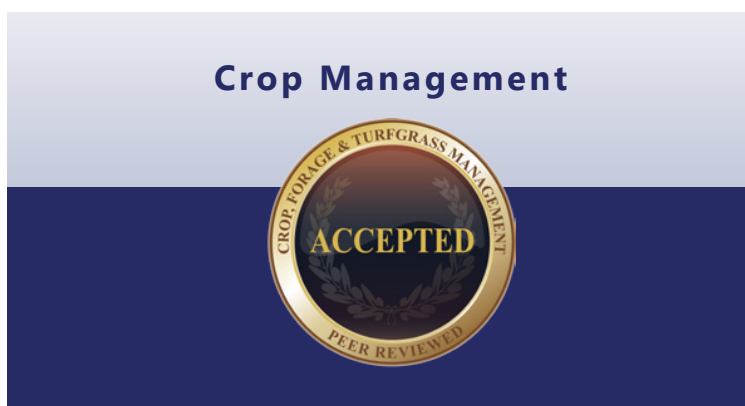

Core Ideas

- Alternative ridging methods could prove beneficial for tobacco producers.

- Conservation tillage efforts have demonstrated little success.

- Fine-textured soils will require special management considerations.

- Soil resistance is considered to be a limiting production factor.

- Coarse-textured soils appear to be better suited than fine-textured soils.

Dep. of Crop and Soil Sciences, North Carolina State Univ., Raleigh, NC 27695. *Corresponding author (matthew_vann@ncsu.edu).

Received 24 Feb. 2017.

Accepted 7 Apr. 2017.

Abbreviations: $B D$, bulk density; $F R$, fall ridging; NR, no ridging; $R R$, rotary ridging; $S R$, spring ridging.

Conversions: For unit conversions relevant to this article, see Table A.

Published in Crop Forage Turfgrass Manage. Volume 3. doi:10.2134/cftm2017.02.0016

(C) 2017 American Society of Agronomy and Crop Science Society of America 5585 Guilford Rd., Madison, WI 53711

This is an open access article distributed under the CC BY-NC-ND license (http://creativecommons.org/ licenses/by-nc-nd/4.0/). 
Table A. Useful conversions.

\begin{tabular}{lcc}
\hline $\begin{array}{l}\text { To convert Column } 1 \text { to Column 2, } \\
\text { multiply by }\end{array}$ & $\begin{array}{c}\text { Column } 1 \\
\text { Suggested Unit }\end{array}$ & $\begin{array}{c}\text { Column } 2 \\
\text { SI Unit }\end{array}$ \\
2.54 & inch & centimeter, $\mathrm{cm}\left(10^{-2} \mathrm{~m}\right)$ \\
0.405 & acre & hectare, ha \\
1.12 & pound per acre, lb/acre & kilogram per hectare, $\mathrm{kg} / \mathrm{ha}$ \\
1 & Grams/cubic centimeter & Megagrams per cubic meter \\
0.1 & bar & megapascal, $\mathrm{MPa}\left(10^{6} \mathrm{~Pa}\right)$ \\
\hline
\end{tabular}

g/cu cm (Alameda et al., 2012; Collins and Hawks, 2013a; Olivet et al., 2014) or 28 bars (Vepraskas and Miner, 1986). After transplanting, secondary cultivation is used to maintain row ridges, suppress weed growth, reduce soil crusting, and incorporate soil-applied pesticides (Vann et al., 2014). Secondary cultivation has also been reported to decrease soil resistance and increase porosity in the Ap horizon of the soil profile (Bathke et al., 1993).

Alternative ridging systems, such as no-till, have proven unsuccessful in the production of flue-cured tobacco (Collins and Hawks, 2013b; Fisher, 2004; Gooden et al., 2008). Yield reduction has been reported at $13 \%$ by Wood and Worsham (1986) and is primarily attributed to dry growing conditions, lacking irrigation infrastructure, low mulch density, and poor root density due to clay soil texture (Fisher, 2004). Strip-tillage in the absence of ridging has produced results only slightly more favorable than those documented in complete no-till systems (Fisher, 2004; Gooden et al., 2008; Jerrell, 2001). Gooden et al. (2008) reported yield and quality reductions (18 and $10 \%$, respectively) in a strip-tillage evaluation, though yield was improved with additional nitrogen and the implementation of secondary cultivation. Increased lodging was also noted by Gooden et al. (2008) when cultivation was not employed. Jerrell (2001) reported a decrease in leaf yield and value in strip-tillage, specifically when ridging was not utilized. Reduced yield and value were attributed to poor growing conditions by Jerrell (2001).

Ultimately, due to the unique nature of tobacco producing systems and the balance that must be maintained between leaf yield and chemistry, SR has consistently produced results more favorable than other ridging and tillage systems. However, tobacco producing operations have significantly increased in size and are often forced to delay field preparation. Given the low rate of success with conservation tillage, other ridging practices warrant investigation. The research contained herein was conducted in 2012 and 2013 to test the hypothesis that alternative tillage systems could deliver yield and quality equivalent to SR in the production of flue-cured tobacco.

\section{Location Descriptions and Plot Establishment}

Experiments were initiated in 2012 at two locations, one in the Coastal Plain production region (Meadow, Johnston County; 35.295N, $-78.452 \mathrm{~W}$ ) and one in the Piedmont production region (Kernersville, Forsyth County; 36.120N, $-80.074 W$ ) of North Carolina. Research was continued in 2013 in the same regions at different field sites, providing four separate environments for treatment evaluation. Transplanting dates, treatments imposed at each location, and treatment establishment dates varied by location and are listed in Table 1. In addition, soil series, soil taxonomic class, $\mathrm{pH}$, and tobacco cultivar are listed in Table 2. Treatments were arranged in a randomized complete block design, replicated four times, and were imposed to individual plots measuring $100 \mathrm{ft}$ in length by four rows in width. The center two rows of each plot were hand-harvested for yield and quality data. Row spacing was 48 and 40 inches in the Piedmont and Coastal Plain locations, respectively. Planting density was 6000 plants/acre. Tobacco was produced using recommendations from the North Carolina Cooperative Extension Service (Fisher, 2014), with the exception of treatments imposed.

Fall ridges were established in conventionally tilled plots in late November/early December of the calendar year previous to which flue-cured tobacco was produced (Table 1). Wheat (Triticum spp.) and barley (Hordeum vulgare L.) were utilized for cover in the Coastal Plain and Piedmont, respectively, and were broadcast applied at $2 \mathrm{bu} /$ acre. Establishment of SR, NR, and RR occurred in the spring of each growing season once soil conditions became favorable (Table 1). Paraquat dichloride (Gramoxone Inteon, Syngenta Crop Protection, Greensboro, NC) was broadcast applied (0.94 lb a.i./acre) at the boot stage of each cover crop approximately 3 to 4 weeks prior to transplanting to ensure adequate kill of vegetative cover. Plots receiving SR treatments at all locations were then disked and bedded with traditional 4-row ridging equipment. In each environment, FR and SR treatments were established with a KMC 6800 Ripper/Bedder (Kelly Manufacturing Company, Tifton, GA). The Ripper/Bedder equipment contained in-row subsoiling shanks at each row, which operated at a depth of approximately 10 inches and were surrounded by discs on each side. The discs pulled soil upward and inward toward the subsoiling shank, thus forming a bed at the center of each row. Rotary ridging was completed with Muratori MZ10C rotary tiller (Allen International Inc., Lehi, UT) containing a leveling 
Table 1. Ridging treatments evaluated, establishment date, transplanting date, and sample dates in 2012 and 2013.

\begin{tabular}{|c|c|c|c|c|c|}
\hline Environment & Treatment ${ }^{+}$ & Establishment & Transplanting & Early sampling & Late sampling \\
\hline \multirow[t]{3}{*}{ Piedmont 2012} & Fall ridging & 2 Nov. & 2 May & 8 May & 3 Oct. \\
\hline & Rotary ridging & 3 Apr. & 2 May & 8 May & 3 Oct. \\
\hline & Spring ridging & 3 Apr. & 2 May & 8 May & 3 Oct. \\
\hline \multirow[t]{3}{*}{ Coastal Plain 2012} & Fall ridging & 28 Nov. & 16 Apr. & 23 Apr. & 14 Sept. \\
\hline & No ridging & 3 Apr. & 16 Apr. & 23 Apr. & 14 Sept. \\
\hline & Spring ridging & 3 Apr. & 16 Apr. & 23 Apr. & 14 Sept. \\
\hline \multirow[t]{3}{*}{ Piedmont 2013} & Fall ridging & 7 Dec. & 10 May & $-\ddagger$ & 10 Sept. \\
\hline & Rotary ridging & 15 Apr. & 10 May & - & 10 Sept. \\
\hline & Spring ridging & 15 Apr. & 10 May & - & 10 Sept. \\
\hline \multirow[t]{3}{*}{ Coastal Plain 2013} & Fall ridging & 21 Nov. & 25 Apr. & 29 May & 5 Sept. \\
\hline & No ridging & 9 Apr. & 25 Apr. & 29 May & 5 Sept. \\
\hline & Spring ridging & 9 Apr. & 25 Apr. & 29 May & 5 Sept. \\
\hline
\end{tabular}

+ Fall ridging occurred in the calendar year previous to which research was conducted.

$\ddagger$ Data not collected due to excessive soil moisture.

Table 2. Soil series, $\mathrm{pH}$, and flue-cured tobacco cultivar at each growing locationt.

\begin{tabular}{l|c|cc|c}
\hline \multicolumn{1}{c|}{ Environment } & Soil series & Taxonomic class & Cultivarł \\
Piedmont 2012 & Fairview sandy clay loam & Fine, kaolinitic, mesic Typic Kanhapludult & 6.2 & NC 196 \\
Coastal Plain 2012 & Blanton sand & Loamy, silicious, semiactive, thermic Grossarenic Paleudult & 5.1 & K 326 \\
Piedmont 2013 & Fairview sandy clay loam & Fine, kaolinitic, mesic Typic Kanhapludult & 6.5 & NC 196 \\
Coastal Plain 2013 & Bibb sandy loam & Coarse-loamy, silicious, active, acid, thermic Typic Fluvaquent & 6.0 & NC 71 \\
\hline
\end{tabular}

† Soil samples were analyzed by the North Carolina Department of Agriculture and Consumer Services using the Mehlich-3 extraction method. ‡ NC 196, Gold Leaf Seed Company, Hartsville, SC; K 326 and NC 71, F.W. Rickard Seeds, Inc., Winchester, KY.

roller that produced a raised ridge with a flat surface. Rotary tillers are tractor-mounted, power takeoff-driven implements designed to mix and pulverize soil to a set depth, resulting in a finer, firmer seedbed (Unger and McCalla, 1980). Subsoiling shanks were not utilized in RR treatments. Ridge height on completion FR, SR, and RR in the two Piedmont environments differed no more than 2 inches. No-ridging treatments in Coastal Plain environments were established with a KMC 6700 Ripper/Stripper (Kelly Manufacturing Company, Tifton, GA) containing subsoiling shanks at each row that operated at an 8-inch depth. Plots were not tilled prior to RR and NR treatment establishment. Rotary ridging and NR treatments were evaluated in separate regions to represent ridging practices employed by producers within those specified areas. Secondary cultivation was employed two or three times within the first 6 weeks following transplanting. Wedge-tine spider wheels were used for secondary cultivation in all treatments to reflect practices employed by cooperating farmers.

\section{Data Collection and Analysis}

\section{Soil Bulk Density, Porosity, and Moisture Content}

Soil BD, porosity, and moisture content were measured two times in the growing season: early (within 1 month following transplanting) and late (immediately after final harvest, before tobacco stalks were destroyed). Results for these parameters were derived from soil samples collected from the soil surface to a depth of 3 inches with a Uhland core sampler (21.2 cu inch/sample). Three random in-row samples were collected from individual plots. Fresh and dry mass was recorded and then averaged within a single plot. Soil mass measurements were used to calculate BD, porosity, and moisture content.

\section{Soil Resistance}

Resistance was measured twice during each growing season (early and late) using a FieldScout SC 900 Soil Compaction Meter (Spectrum Technologies, Aurora, IL). Resistance measurements were recorded at 1-inch intervals within the soil profile from the soil surface ( 0 inches) to a depth of 16 inches. Three measurements were collected from each plot and were organized into four separate soil depth groups $(0-4,4-8$, $8-12$, and 12-16 inches) for statistical analysis.

\section{Yield, Quality, and Value}

Leaf yield data were collected from 50 plants within the center two rows of each plot. Subsamples of harvested leaf samples were cured and assigned a USDA grade. Each grade describes the leaf maturity and ripeness and has an associated index value and price (Bowman et al., 1988). Crop value was determined using a combination of leaf yield and quality with price indices reported by Fisher et al. (2014). 
Table 3. Tobacco yield, quality, and value response to ridging treatments in the Piedmont and Coastal Plain Growing Regions of North Carolina.

\begin{tabular}{|c|c|c|c|c|c|c|}
\hline \multirow[b]{2}{*}{ Treatment } & \multicolumn{3}{|c|}{ Piedmont } & \multicolumn{3}{|c|}{ Coastal Plain ${ }^{\dagger}$} \\
\hline & Yield & Quality & Value & Yield & Quality & Value \\
\hline & lb/acre & & \$/acre & lb/acre & & \$/acre \\
\hline Fall ridging & $2906 \mathrm{~b} \S$ & 85 a & $5375 \mathrm{~b}$ & 2182 a & $85 a$ & $4030 \mathrm{a}$ \\
\hline Rotary ridging & 3327 a & $85 a$ & $6128 \mathrm{a}$ & N/AII & N/A & N/A \\
\hline No ridging & N/A & N/A & N/A & $2275 a$ & $85 \mathrm{a}$ & $4201 \mathrm{a}$ \\
\hline Spring ridging & 3218 a & $85 \mathrm{a}$ & 5948 a & 2016 a & $85 \mathrm{a}$ & 3611 a \\
\hline$P>F$ & 0.01 & -\# & 0.02 & 0.34 & - & 0.28 \\
\hline$C V, \%$ & 7.9 & 0 & 8.1 & 10.7 & 0 & 12.3 \\
\hline
\end{tabular}

+ One year of data reported due to significant hail damage in 2012.

$\ddagger$ Quality assessed on a scale of 1 to 100, with 100 having the highest quality.

$\S$ Means followed by the same letter within a specified parameter are not significantly different at the $\alpha=0.10$ level. Data within the Piedmont location are pooled over two environments.

II N/A, treatment not evaluated within the specified growing region.

$\# \boldsymbol{P}>\boldsymbol{F}$ value not generated due to no variation among treatment response.

Table 4. Early- and late-season soil penetration resistance as affected by ridging treatments in the Piedmont of North Carolina.

\begin{tabular}{|c|c|c|c|c|}
\hline \multirow[b]{2}{*}{ Treatment } & \multicolumn{4}{|c|}{ Soil depth group } \\
\hline & $0-4$ inches & $4-8$ inches & $8-12$ inches & $12-16$ inches \\
\hline \multicolumn{5}{|l|}{ Early seasont } \\
\hline Fall ridging & 1.3 af & $26.1 \mathrm{a}$ & $34.7 \mathrm{a}$ & $38.2 \mathrm{a}$ \\
\hline Rotary ridging & $0.8 \mathrm{~b}$ & $7.1 \mathrm{~b}$ & $22.0 \mathrm{~b}$ & $25.4 \mathrm{~b}$ \\
\hline Spring ridging & $0.8 \mathrm{~b}$ & $5.8 \mathrm{~b}$ & $20.1 \mathrm{~b}$ & $28.9 \mathrm{~b}$ \\
\hline$P>F$ & 0.03 & 0.01 & 0.04 & 0.02 \\
\hline $\mathrm{CV}, \%$ & 23.9 & 37.6 & 26.4 & 13.1 \\
\hline \multicolumn{5}{|l|}{ Late season } \\
\hline Fall ridging & $2.6 \mathrm{a}$ & $7.6 \mathrm{a}$ & $11.7 \mathrm{a}$ & $16.8 \mathrm{~b}$ \\
\hline Rotary ridging & $3.0 \mathrm{a}$ & $7.9 \mathrm{a}$ & $18.4 \mathrm{a}$ & 25.7 a \\
\hline Spring ridging & $2.6 \mathrm{a}$ & $7.2 \mathrm{a}$ & $15.9 \mathrm{a}$ & $23.5 \mathrm{a}$ \\
\hline$P>F$ & 0.54 & 0.75 & 0.31 & 0.08 \\
\hline $\mathrm{CV}, \%$ & 34.2 & 24.4 & 54.5 & 33.1 \\
\hline
\end{tabular}

† 2013 early season data not collected due to excessive soil moisture; data represent one environment.

$\ddagger$ Means followed by the same letter within a specified soil depth group and environment are not significantly different at the $\alpha=0.10$ level. Data are pooled across two environments.

\section{Data Analysis}

Due to differences in treatments and soil conditions, results from the Piedmont and Coastal Plain regions were analyzed and reported independent of one another. Data were subjected to analysis of variance using the PROC GLM procedure in SAS v. 9.4 (SAS Institute, Inc., Cary, NC). Where appropriate, results are pooled across growing seasons within a growing environment. Treatment means were separated using Fisher's Protected LSD at $p \leq 0.10$.

\section{Effect of Ridging in the Piedmont Environment}

Leaf yield and value in the Piedmont was reduced in FR treatments (Table 3), most likely due to increased soil resistance early in the growing season (Table 4). Soil resistance and tobacco root growth are inversely related; therefore, as soil resistance is increased, root growth and leaf yield are likely to be reduced (Alameda et al., 2012; Olivet et al., 2014; Vepraskas and Miner, 1986). Results are similar to those reported by Bathke et al. (1993), who documented a yield reduction of 340 lb/acre where tobacco was produced in a FR system located within the Piedmont region of North Carolina. Leaf quality was not affected by ridging system (Table 3). 
Table 5. Early- and late-season soil physical properties as affected by ridging treatments in the Piedmont of North Carolina in 2012 and 2013.

\begin{tabular}{|c|c|c|c|c|c|c|}
\hline \multirow[b]{2}{*}{ Treatment } & \multicolumn{3}{|c|}{ Early season } & \multicolumn{3}{|c|}{ Late season } \\
\hline & Bulk density & Porosity & Water content & Bulk density & Porosity & Water content \\
\hline & $\mathrm{g} / \mathrm{cu} \mathrm{cm}$ & 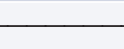 & $\longrightarrow$ & $\mathrm{g} / \mathrm{cu} \mathrm{cm}$ & 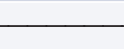 & $\longrightarrow$ \\
\hline \multicolumn{7}{|l|}{2012} \\
\hline Fall ridging & 1.51 at & $43 \mathrm{a}$ & $9.0 \mathrm{a}$ & $1.46 \mathrm{~b}$ & $45 \mathrm{a}$ & $17.5 \mathrm{a}$ \\
\hline Rotary ridging & $1.42 \mathrm{a}$ & $47 \mathrm{a}$ & $10.5 \mathrm{a}$ & $1.52 \mathrm{a}$ & $43 \mathrm{~b}$ & $14.0 \mathrm{~b}$ \\
\hline Spring ridging & $1.42 \mathrm{a}$ & $47 \mathrm{a}$ & $11.3 \mathrm{a}$ & $1.47 \mathrm{~b}$ & $45 \mathrm{a}$ & $15.5 \mathrm{ab}$ \\
\hline$P>F$ & 0.56 & 0.60 & 0.13 & 0.05 & 0.06 & 0.09 \\
\hline $\mathrm{CV}, \%$ & 9.5 & 11.5 & 13.1 & 2.0 & 2.5 & 12.0 \\
\hline \multicolumn{7}{|l|}{2013} \\
\hline Fall ridging & $-\ddagger$ & - & - & $1.25 \mathrm{~b}$ & $53 \mathrm{a}$ & $14.3 \mathrm{a}$ \\
\hline Rotary ridging & - & - & - & $1.33 \mathrm{a}$ & $50 \mathrm{~b}$ & $13.3 \mathrm{a}$ \\
\hline Spring ridging & - & - & - & $1.34 \mathrm{a}$ & $50 \mathrm{~b}$ & $12.3 \mathrm{a}$ \\
\hline$P>F$ & - & - & - & 0.01 & 0.03 & 0.19 \\
\hline $\mathrm{CV}, \%$ & - & - & - & 2.5 & 2.9 & 10.1 \\
\hline
\end{tabular}

t Means followed by the same letter within a specified parameter and growing location are not significantly different at the a $=0.10$ level.

$\ddagger 2013$ early-season data not collected due to excessive soil moisture.

Ridging treatments did not affect early-season BD, porosity, or water content in 2012 (Table 5). However, FR treatments resulted in the greatest resistance measurements for all soil depth groups (Table 4). On average, soil resistance in the FR treatment was 1.5 to 4.5 times greater than in the RR and NR treatments (Table 4). Vepraskas and Miner (1986) report that tobacco root growth is inhibited when soil resistance is $>28$ bars below the Ap horizon. Soil resistance was 26.1 bars at a depth range as shallow as 4 to 8 inches and surpassed 28 bars as depth within the soil profile increased (Table 4). Although results were not statistically significant, FR treatments contained the highest $\mathrm{BD}$, lowest porosity, and lowest water content (Table 5); therefore, it is plausible that these effects to soil resistance were amplified given low rainfall accumulation ( $<2.25$ inches) in the month prior to early-season data collection. Bathke et al. (1993) reported greater resistance in FR treatments compared with SR treatments and hypothesized that low rainfall might be the contributing factor in a Piedmont environment.

Late-season soil BD was lowest in FR treatments, which translated into the highest soil porosity and water content measurements among all treatments (Table 5). Resistance measurements declined in the FR treatment late season (Table 4), which is likely due to increased soil water content at the same interval (Table 5). The cumulative rainfall total for the month prior to the late-season sampling interval was 4.65 and 5.67 inches in 2012 and 2013, respectively. Rainfallincreased soil water content can reduce internal friction between soil particles, thus allowing for easier penetration by plant roots (Hillel, 1998). However, late-season improvements in soil physical properties are likely to have occurred too late in the growing season to improve leaf yield and value in FR treatments.

\section{Effect of Ridging in the Coastal Plain Environment}

Crop performance and soil physical properties (BD, porosity, and water content) were not affected by ridging treatments (Tables 3 and 6). Results follow a similar trend reported by Bathke et al. (1993), who observed similar soil BD and porosity when comparing FR and SR systems in the Coastal Plain region of North Carolina. Alternatively, results from NR treatments are in conflict with those reported by Gooden et al. (2008) and Jerrell (2001), most likely due to better growing conditions experienced in this study and the use of secondary cultivation.

In the early 2012 soil resistance measurements, treatment differences were observed within the 0 - to 4 -inch depth range, though none were high enough to inhibit plant growth and development (Table 7) and did not impact crop development (Table 6). Early-season treatment differences were not observed in soil depth groups 4 to 8 or 8 to 12 inches; however, resistance was greatest in strip-tillage treatments (39.6 bars) at the 12- to 16-inch depth range (Table 7). In 2013, treatment differences were observed in early- and late-season measurements at depths $>8$ inches (Table 7). In general, NR resulted in the highest penetration resistance and FR resulted in the lowest penetration resistance (Table 7). Across both years of evaluation, soil resistance was never greater than the 28-bar limit put forth by Vepraskas and Miner (1986) at depths shallower than 12 inches (Table 7), where the majority of tobacco root growth occurs within the soil profile (Collins and Hawks, 2013b). Results from this study are in agreement with Bathke et al. (1993), who did not observe soil resistance differences in FR and SR systems in soil depths shallower than 12 inches in a Coastal Plain environment. 
Table 6. Early- and late-season soil physical properties as affected by ridging treatments in the Coastal Plain of North Carolina.

\begin{tabular}{|c|c|c|c|c|c|c|}
\hline \multirow[b]{2}{*}{ Treatment } & \multicolumn{3}{|c|}{ Early season } & \multicolumn{3}{|c|}{ Late season } \\
\hline & Bulk density & Porosity & Water content & Bulk density & Porosity & Water content \\
\hline & $\mathrm{g} / \mathrm{cu} \mathrm{cm}$ & 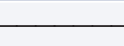 & 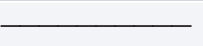 & $\mathrm{g} / \mathrm{cu} \mathrm{cm}$ & 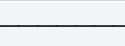 & 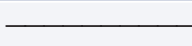 \\
\hline Fall ridging & 1.41 at & 47 a & $8.1 \mathrm{a}$ & $1.40 \mathrm{a}$ & 47 a & $5.5 \mathrm{a}$ \\
\hline No ridging & $1.43 \mathrm{a}$ & $46 a$ & $8.3 \mathrm{a}$ & $1.40 \mathrm{a}$ & $47 a$ & $6.0 \mathrm{a}$ \\
\hline Spring ridging & $1.43 \mathrm{a}$ & $46 \mathrm{a}$ & $8.1 \mathrm{a}$ & $1.40 \mathrm{a}$ & $47 \mathrm{a}$ & $5.8 \mathrm{a}$ \\
\hline$P>F$ & 0.39 & 0.52 & 0.89 & 1.0 & 0.97 & 0.12 \\
\hline$C V, \%$ & 2.4 & 2.8 & 7.5 & 2.4 & 2.6 & 7.7 \\
\hline
\end{tabular}

† Means followed by the same letter within a specified parameter and growing location are not significantly different at the $\alpha=0.10$ level. Data are pooled over two environments.

Table 7. Early- and late-season soil penetration resistance as affected by ridging treatments in the Coastal Plain of North Carolina in 2012 and 2013.

\begin{tabular}{|c|c|c|c|c|}
\hline \multirow[b]{2}{*}{ Treatment } & \multicolumn{4}{|c|}{ Soil depth group } \\
\hline & $0-4$ inches & $4-8$ inches & $8-12$ inches & $12-16$ inches \\
\hline & & & 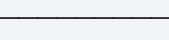 & 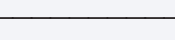 \\
\hline \multicolumn{5}{|l|}{2012 Early season } \\
\hline Fall ridging & $0.4 \mathrm{bt}$ & $2.8 \mathrm{a}$ & $12.9 \mathrm{a}$ & $32.9 \mathrm{~b}$ \\
\hline No ridging & $0.7 \mathrm{a}$ & $2.0 \mathrm{a}$ & $9.8 \mathrm{a}$ & $39.6 \mathrm{a}$ \\
\hline Spring ridging & $0.2 \mathrm{c}$ & $2.1 \mathrm{a}$ & $12.3 \mathrm{a}$ & $31.5 \mathrm{~b}$ \\
\hline$P>F$ & 0.01 & 0.44 & 0.64 & 0.10 \\
\hline $\mathrm{CV}, \%$ & 30.7 & 41.1 & 40.8 & 46.4 \\
\hline \multicolumn{5}{|l|}{2012 Late season } \\
\hline Fall ridging & $1.2 \mathrm{a}$ & $5.1 \mathrm{a}$ & $13.2 \mathrm{a}$ & $37.1 \mathrm{a}$ \\
\hline No ridging & $1.2 \mathrm{a}$ & $4.7 \mathrm{ab}$ & $9.2 \mathrm{a}$ & $28.3 \mathrm{a}$ \\
\hline Spring ridging & $0.8 \mathrm{a}$ & $3.9 \mathrm{~b}$ & $13.0 \mathrm{a}$ & $33.7 \mathrm{a}$ \\
\hline$P>F$ & 0.53 & 0.09 & 0.63 & 0.66 \\
\hline $\mathrm{CV}, \%$ & 55.0 & 14.0 & 53.7 & 34.9 \\
\hline \multicolumn{5}{|l|}{2013 Early season } \\
\hline Fall ridging & $0.9 \mathrm{a}$ & $3.8 \mathrm{a}$ & $4.5 \mathrm{~b}$ & $21.7 \mathrm{a}$ \\
\hline No ridging & $0.7 \mathrm{a}$ & $3.7 \mathrm{a}$ & $5.6 \mathrm{~b}$ & $23.2 \mathrm{a}$ \\
\hline Spring ridging & $0.9 \mathrm{a}$ & $3.8 \mathrm{a}$ & $12.9 \mathrm{a}$ & $34.0 \mathrm{a}$ \\
\hline$P>F$ & 0.55 & 0.89 & 0.03 & 0.36 \\
\hline $\mathrm{CV}, \%$ & 25.1 & 12.7 & 46.1 & 46.4 \\
\hline \multicolumn{5}{|l|}{2013 Late season } \\
\hline Fall ridging & $1.0 \mathrm{a}$ & $3.0 \mathrm{a}$ & $4.2 \mathrm{~b}$ & $11.1 \mathrm{~b}$ \\
\hline No ridging & $1.0 \mathrm{a}$ & $2.8 \mathrm{a}$ & $6.5 \mathrm{a}$ & $9.6 \mathrm{~b}$ \\
\hline Spring ridging & $0.8 \mathrm{a}$ & $2.9 \mathrm{a}$ & $7.4 \mathrm{a}$ & $20.5 \mathrm{a}$ \\
\hline$P>F$ & 0.79 & 0.90 & 0.05 & 0.08 \\
\hline $\mathrm{CV}, \%$ & 43.7 & 22.4 & 24.8 & 46.6 \\
\hline
\end{tabular}

† Means followed by the same letter within a specified soil depth group and environment are not significantly different at the $\alpha=0.10$ level.

\section{Conclusions}

Of the four ridging systems evaluated, FR provides the greatest benefit to producers from a time management standpoint due the creation of raised plant beds 4 to 5 months prior to transplanting. However, due to high soil resistance, FR may not be consistently suitable for fine-textured soils similar to those found in the Piedmont area of North Carolina evaluated in this study. If FR is used in fine-textured soils, then additional practices, such as in-row subsoiling prior to transplanting should be considered to alleviate resistance issues. Alternatively, soil resistance does not appear to be a limiting factor for tobacco growth when FR is employed to environments with coarse-textured soil. Rotary ridging performed similar to conventional SR methods; however, it is not recommended due to the negative long-term effects the machinery has on soil structure (Troeh and Thompson, 2005). Field sites could potentially be left void of ridging altogether in certain environments, as was demonstrated through 
acceptable results obtained from NR treatments. Should this practice be utilized, producers should use stripping-ripping equipment similar to that reported in this study. The simultaneous stripping and ripping allows for good seedling-soil contact and is believed to have reduced in-row soil resistance.

Tillage programs differing from conventional SR have advantages in flue-cured tobacco production in North Carolina. Along with acceptable leaf yield, quality, and value, alternative tillage systems might address other production issues, such as soil erosion, water and nutrient runoff, sand blasting, soil resistance, moisture availability, and timely implementation of agronomic practices (Benham et al., 2007; Jones, 1998). Producers are encouraged to consider alternative ridging systems such as FR or NR, depending on geographic location and general production practices, but should be aware that all tillage systems are not always suitable in the differing environments of North Carolina.

\section{References}

Alameda, D., N.P.R. Anten, and R. Villar. 2012. Soil compaction effects on growth and root traits of tobacco depend on light, water regime, and mechanical stress. Soil Tillage Res. 120:121129. doi:10.1016/j.still.2011.11.013

Bathke, G.R., A.D. Worsham, and C.B. McCants. 1993. Primary and secondary tillage effects on soil properties and tobacco production. Tob. Sci. 37:4-8

Benham, B.L., D.H. Vaughan, M.K. Laird, B.B. Ross, and D.R. Peek. 2007. Surface water quality impacts of conservation tillage practices on burley tobacco production systems in southwest Virginia. Water Air Soil Pollut. 179:159-166. doi:10.1007/s11270006-9221-z

Bowman, D.T., A.G. Tart, E.A. Wernsman, and T.C. Corbin. 1988. Revised North Carolina grade index for flue-cured tobacco. Tob. Sci. 32:39-40

Collins, W.K., and S.N. Hawks. 2013a. Climate and soils. In: W.K. Collins, editor, Principles of flue-cured tobacco production. 2nd ed. Hawks \& Collins, Raleigh, NC. p. 15-20.

Collins, W.K., and S.N. Hawks. 2013b. Cultivation and weed management. In: W.K. Collins, editor, Principles of flue-cured tobacco production. 2nd ed. Hawks \& Collins, Raleigh, NC. p. 67-69.

Fisher, L.R. 2004. Potential for reduced tillage tobacco production in North Carolina. In: Proceedings of the 26th Southern Conservation Tillage Conference for Sustainable Agriculture, Raleigh, NC. 8-9 June 2004. p. 161-162.
Fisher, L.R., editor. 2014. 2014 North Carolina State University fluecured tobacco production guide (AG-187 (revised)). North Carolina Coop. Ext. Serv., Raleigh.

Fisher, L.R., M.C. Vann, G. Tart, and K. Barnes. 2014. Selecting a variety. In: L.R. Fisher, editor, 2014 North Carolina State University flue-cured tobacco production guide (AG-187 (revised)). North Carolina Coop. Ext. Serv., Raleigh. p. 23-44.

Gooden, D.T., B.A. Fortnum, and H.D. Skipper. 2008. Flue-cured tobacco in a strip-till production system. Tob. Sci. 47:29-33. doi:10.3381/1956.1

Hillel, D. 1998. Soil dynamics: Stress, strain, and strength. In: D. Hillel, editor, Environmental soil physics. Academic Press, London. p. 341-382.

Jerrell, S.L. 2001. Strip-tillage production systems for tobacco. M.S. thesis, Virginia Polytechnic Inst. and State Univ. https://vtechworks.lib.vt.edu/bitstream/handle/10919/33132/FinalThesis. PDF?sequence=1\&isAllowed=y (accessed 15 Feb. 2017).

Jones, B.G. 1998. Impact of conservation tillage on soil erosion and the agronomic performance of flue-cured tobacco. M.S. thesis, Virginia Polytechnic Inst. and State Univ. https://vtechworks.lib. vt.edu/handle/10919/40537 (accessed 15 Feb. 2017).

Olivet, Y.E., V. Sanchez-Giron, and J.L. Hernanz. 2014. Reduced tillage for tobacco (Nicotiana tabacum L.) production in east Cuba. Soil physical properties and crop yield. Span. J. Agric. Res. 12(3):611-622. doi:10.5424/sjar/2014123-5625

Peedin, G.F. 1999. Production practices: Flue-cured tobacco. In: D.L. Davis and M.T. Nielsen, editors, Tobacco production, chemistry, and technology. Blackwell Sci., Malden, MA. p. 104-142.

Troeh, F.R., and L.M. Thompson. 2005. Physical properties of soils. Soils and soil fertility. 6th ed. Blackwell Publ., Ames, IA. p. 37-64.

Unger, P.W., and T.M. McCalla. 1980. Conservation tillage systems. Adv. Agron. 33:1-58. doi:10.1016/S0065-2113(08)60163-7

Vann, M.C., L.R. Fisher, J.A. Priest, and D.S. Whitley. 2014. Managing weeds. In: L.R. Fisher, editor, 2014 North Carolina State University flue-cured tobacco production guide (AG-187 (revised)). North Carolina Coop. Ext. Serv., Raleigh. p. 78-98.

Vepraskas, M.J., and G.S. Miner. 1986. Effects of subsoiling and mechanical impedance on tobacco root growth. Soil Sci. Soc. Am. J. 50:423-427. doi:10.2136/sssaj1986.03615995005000020034x

Wood, S.D., and A.D. Worsham. 1986. Reducing soil erosion in tobacco fields with no-tillage transplanting. J. Soil Water Conserv. 41(3):193-196. 